<原 著 $>$

合成女性ホルモンによる肝癌発生の実験的研究

特に肝細胞癌のホルモン依存性について

\title{
上原 伸一*
}

要 旨：経口避妊薬の肝発癌性, 並び発生した肝腫瘍のホルモン依存性を検索する目的で以 下の研究を行った. 生後 4 週秢のWistar/JCL 雌ラットに硬性胃ゾンデを用いて每日強制的に 1 年間にわたり下記の薬剤を 1 日 1 回投与した。 I 群：ethinylestradiol $0.075 \mathrm{mg}+$ norethindrone acetate $6 \mathrm{mg}$ in $0.5 \mathrm{~m} l$ olive oil, II 群 : I 群の倍量. III 群・IV 群 : I 群及び II 群の対照 として olive oil のみをそれぞれ $0.5 \mathrm{~m} l$ または $1.0 \mathrm{~m} l$. 薬剤投与終了の時点で, 対照としたIII群 及びIV群では全く畽場の発生を認めなかったが, I 群：38匹中 6 匹（15.8\%), II 群：27匹中 6 匹（22.2\%）に高分化型肝細胞癌の発生を認めた。ついでホルモンの投与を中止したところ， これらの肝細胞癌はしだいに縮少した。またこれらの肝細胞癌では腫場細胞の核又は胞体内に estrogen receptor が検出された，以上より経口避娃薬は単独で肝細胞癌を発生せしめ, 発生し た肝癌は著明なホルモン依存性を示し，かつこれらの発現の上で estrogen receptor の関与が 示唆された。

索引用語： 経口避妊薬の発癌性肝腫煌のホルモン依存性 estrogen receptor

\section{緒 言 \\ ステロイドホルモン投与による肝腫煬の発生に関す} る報告は1953年 Caroli ら゙ににはじるが，1971年 Bernstein ら ${ }^{21} か 3$ Fanconi 負血に対する oxymetholone 治 療中に肝腫瘍が発生したことを報告して以来 androgenic anabolic steroid による肝癌発生の報告が多 数みられるようになっている。一方経口避妊薬服用に よる肝腫煌の発生は1972年 Horvath らがはじめて 報告し,さらに1973年 Baum ら゙が 7 例の hepatic cell adenoma 報告して以来経口避妊薬服用女性に肝細 胞腺腫や肝細胞癌が発生したといら報告が相次ぎ注目 を集めるようになってきた，本本ら5)は1973年〜1981 年の世界の文献から経口避妊薬の服用と関連があると 思われる肝腫瘍を340例集計しており，良性腫煌として は liver cell adenoma 172例, focal nodular hyperplasia 139例，悪性尰痬は hepatocellular carcinoma 24例, hepatoblastoma 2 例, angiosarcoma 2 例, mixed hepatocellular-ductal carcinoma 1 例であっ た。しかしながら実験的に合成女性ホルモンを単独投 与して肝腫瘍の発生につき検索した研究は1970年

-三重大学第 1 外科学教室（主任：水本能二教授） <受付日60年 7 月 5 日 $>$
Schardein $5^{6)} 1972$ 年 Committee on Safety of Medicines (London) $)^{7}$ な゙の報告が散見されるにす ぎず，いずれも肝癌の発生を認めていない。

われわれの教室では Wistar/JCL 雌ラットに程口 避妊薬の配合にあわせて estrogen と progestogenの 合成女性ホルモンを連日経口投与したところ 4 力月目 より全例の肝に過形成結節の発生を認め，以後投与期 間の延長とともにその数や面積が增加し，ついで 8 カ 月目からは高分化型肝細胞癌の発生を認め,さらにホ ルモンの投与を中止すると発生した過形成結節はその 数, 面積ともに減少することを報告してきた ${ }^{820)}$. 本研 究は経口避妊薬の肝発癌性を再検討するととるに，発 生する肝細胞癌のホルモン依存性を明らかにする目的 で行われた。

\section{実験材料及び方法}

体重50 60g の生後 4 週龄の Wistar/JCL 䧳ラット (CLEA, Japan, Inc. Tokyo)を用い，5 匹ずつ plastic cage に分け, 三重大学医学部中央動物実験施設におい て室温 $20 \sim 25^{\circ} \mathrm{C}$ の空調室で, 固形飼料 CE-2 (CLEA) 及び水道水を自由に与えて飼育した。なお実験に用い たラットは投与薬剤の種類と量により次の 4 群に分 け，硬性胃ゾンデを用い， 1 日 1 回每日強制的に 1 年 間にわたり薬郕を胃内に投与した。 
$50: 458$

I 群 (52匹) : ethinylestradiol $0.075 \mathrm{mg}$ 及び norethindrone acetate $6 \mathrm{mg} を 0.5 \mathrm{~m} l$ の olive oil に溶解 し、これを 1 回投与量とした.

II 群 (47匹) : ethinylestradiol $0.15 \mathrm{mg}$, norethindrone acetate $12 \mathrm{mg}$ を $1.0 \mathrm{~m} l$ の olive oil に溶解して ( I 群の 2 倍量)， 1 回投与量とした.

III群 (38匹), IV群 ( 5 匹) : olive oil のみ0.5m $l$ 又 は $1.0 \mathrm{~m} l$ を 1 回投与量とし，それぞれI群及びII群の 対照群とした。

各群ともに 1 年間の薬剤投与完了の翌日エーテル麻 酔下に開腹して以下の検索を行った。

実験 I：合成女性ホルモンの投与による肝病变の発 生と莱绪投与中止の効果

開腹して肉眼的に肝董湯の発生を認めなかったラッ トは值らに儀牲剖検して肝並びに全身諸䟵器の変化を 観察した。肝腫場の発生を認めたラットは生検で組織 学的に肝癌であることを確診した後一旦閉腹し，以後 薬剤の投与を中止したまま 1 カ月毎に開腹して肝腫啺 の変化を観察した。なお肝組織切片は10\%リン酸緩衝 ホルマリン液で固定しハララフィン包埋後 Hematoxylin-eosin (H-E) 染色を行った. 又一部は冷アセトン にて固定後 Rutenburg 法により $\gamma$-glutamyltranspeptidase（ $\boldsymbol{\gamma}$-GTPase）染色を行い，一部は凍結切片を 作製し Wachstein-Meisel 法にて adenosine triphosphatase (ATPase) 染色を行ってこれらの変化を組織 学的に検索した.

実験 II：肝組織内における estrogen receptor の 検索

実験 I における肝の腫湯部, 非尰煬部及び対照とし て正常ラット肝のそれぞれ組織切片を採取後ただちに
Table 1 Procedure of PAP method for demonstrating intracellular estrogen-binding in paraffin sections.

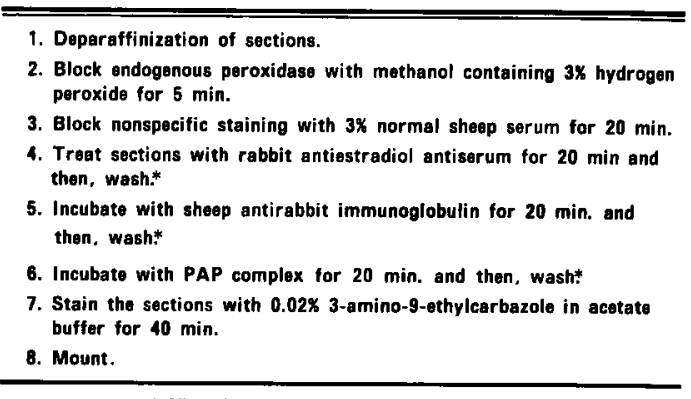

* All washes ware done by Phosphate Bulfered Seline (PBS)

その一部をー $70^{\circ} \mathrm{C} て ゙$ 涷結し， dextran coated charcoal 法を用いて, estrogen receptor を測定した。な打解離 定数 (Kd) $10^{-9} \mathrm{~mol} / l$ 以下, 最大結合部位数 $6 \mathrm{FMOL} /$ $\mathrm{mg}$ 以上を estrogen receptor 陽性と判定した. 又腫瘍 部及び非睡場部における肝組織切片の一部は $10 \%$ ン 酸緩衝ホルマリン液で固定後ハラフィン包埋し, antiestradiol を用いる peroxidase-antiperoxidase DeLellis 変法 (Table 1) にて組織化学的に組織内の estrogen 検索した。

\section{実験成績}

対照として olive oil のみを投与したIII群, IV群では 経過中の死亡例はなかったか，I群52匹中14匹 (26.9\%)，II 群47匹中20匹 (42.6\%) か薬郕投与完了前 に死亡し,死因はいずれも肺炎もしくは肺膿場であり， これらは今回の検索対象から除外した。したがって1 年間にわたる薬剤投与を完了し，以下の検索に用いる ことのできた動物数は I 群38匹, II 群27匹, III群38匹,

Table 2 Various tumors developed in rats at the end of the hormone administration.

\begin{tabular}{|c|c|c|c|c|c|c|c|}
\hline \multirow{2}{*}{\multicolumn{2}{|c|}{ Experimental Group }} & \multirow{2}{*}{$\begin{array}{l}\text { Initial No. } \\
\text { of Rats }\end{array}$} & \multirow{2}{*}{$\begin{array}{l}\text { Effective No. } \\
\text { of Rats }\end{array}$} & \multirow{2}{*}{ HCC } & \multirow[t]{2}{*}{ HN } & \multicolumn{2}{|c|}{$\begin{array}{l}\text { Tumor in the } \\
\text { oxtrahepetic tissue }\end{array}$} \\
\hline & & & & & & B roast & Soft tissue \\
\hline $\begin{array}{c}\text { Hormone } \\
\text { Administration }\end{array}$ & $\begin{array}{l}\text { Group I } \\
\text { (aingle dose) } \\
\text { Group II } \\
\text { (double dose) }\end{array}$ & $\begin{array}{l}52 \\
47\end{array}$ & $\begin{array}{l}38 \\
27\end{array}$ & $\begin{array}{c}6 \\
(15.8 x) \\
6 \\
(22.2 x)\end{array}$ & $\begin{array}{c}38 \\
(100 x) \\
27 \\
2100 \%)\end{array}$ & 1 & 1 \\
\hline Control & $\begin{array}{l}\text { Group III } \\
\text { Group IV }\end{array}$ & 38 & 38 & 0 & 0 & & \\
\hline
\end{tabular}


IV群 5 匹である.

実験 I：合成女性ホルモンの投与による肝病变の発 生と菜都投与中止の効果

1. 肝の形態的変化 (Table 2)

a) 肝過形成結節の発生

合成女性ホルモンを投与した I 群38匹，II 群27匹の 計65匹の全例の肝に肉眼的に1 2 $\mathrm{mm}$ 以下の白色小結 節が散在性に認められ，これら小結節は組織学的に肝 小葉の一部を占めるものから小葉数個の大きさに及ら゙ ものまであり,これらの病宩では肝細胞索が正常の構 造を示さず，静脈洞を欠き，細胞が石垣状に増生して 周囲の正常肝細胞索を王排していた．またこれらの細 胞は clear cell あるいは eosinophilic cell よりなり分 裂像はほとんど羿められず (Fig. 1)，組織化学的には $\gamma$-GTPase 陽性，ATPase 陰性で過形成結節と考えら れた (Fig. 2).

一方，対照として olive oil のみを投与したIII群・IV 群の肝には過形成結節の発生は全く認められなかっ た.

b）肝細胞癌の発生

合成女性ホルモンの投与を12力月間完了後, I 群 (single dose) 38匹中 6 匹 (15.8\%), II 群 (double dose）27匹中 6 匹 $(22.2 \%)$ に肝腫瘍の発生が認めら れた。 発生した肝腫場は肉眼的に白色ないし淡褐色調

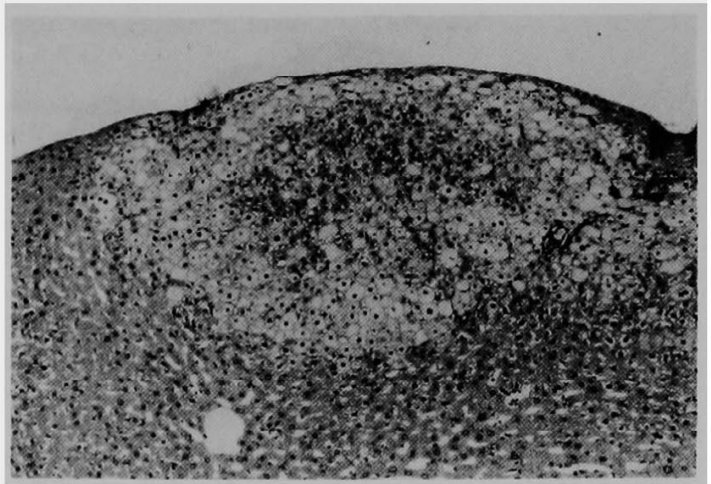

Fig. 1 Hyperplastic nodule developed in the liver of female rats after the hormone administration. The cells composing nodule are considerably large and contain abundunt cytoplasm with various degrees of eosinophilia. H-E stain, $\times 100$.

を呈し周辺との境界明瞭な充実性畽湯で（Fig. 3A）, 割面では処々にblood lake が認められた (Fig. 3B). I 群の肝畽場は最大 $40 \times 35 \mathrm{~mm}$ の 1 個の他はいずれる腫 塲径 $9 \mathrm{~mm}$ 以下で, 最小 $3 \times 2 \mathrm{~mm}$, いずれも単発で 6 個 中 5 個が left lateral lobe, 1 個が right lateral lobe に認められた。II 群の肝腫場は最大 $22 \times 22 \mathrm{~mm}$, 最小 $7 \times 7 \mathrm{~mm}$ で 6 匹中 3 匹に 2 個の肝腫場の発生を認めて 扰り合計 9 個中, 1 個が left lateral lobe, 2 個が left
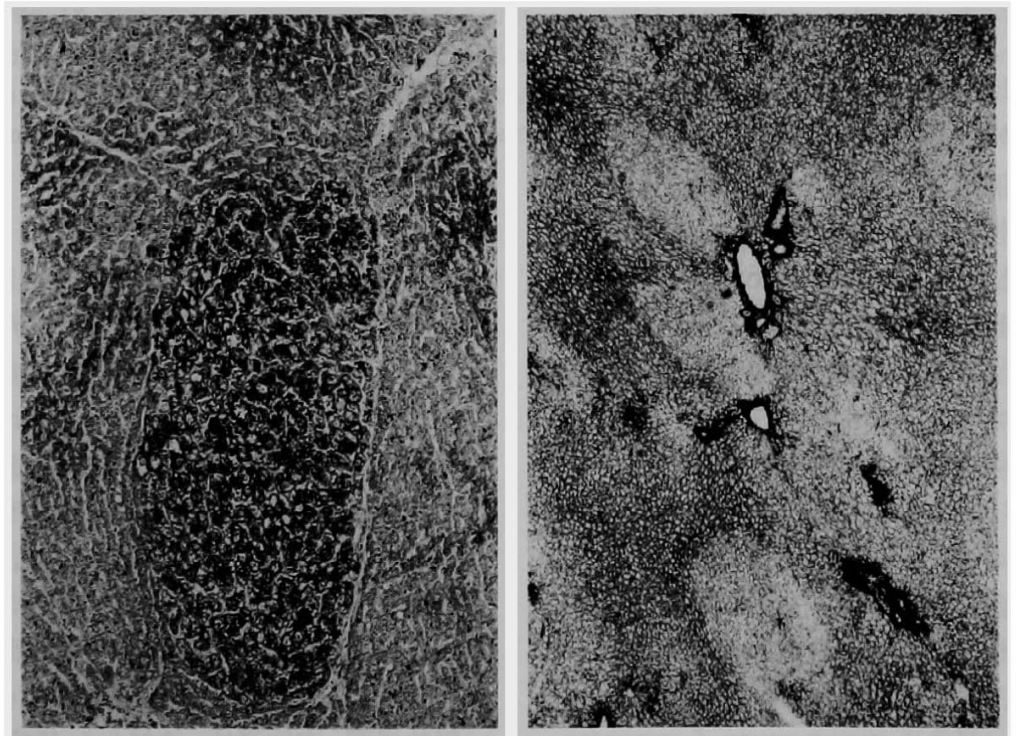

Fig. 2 Hyperplastic nodule of the liver showing marked increase of $\gamma$-GTPase activity (left: Rutenburg's method, $\times 40$ ) and loss of canalicular ATPase activity (right: Wachstein-Meisel's method, $\times 10$ ). 


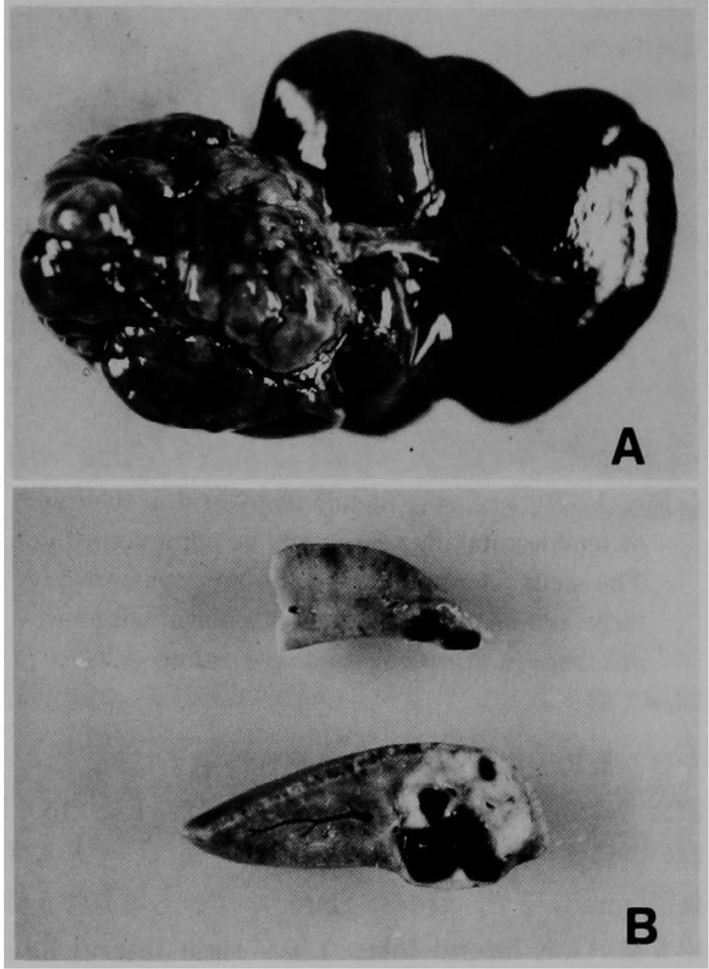

Fig. 3 Liver tumors developed after the hormone administration. (A) : gross appearance of one of the liver tumors in group I (single dose) (B) : cut surface of one of the liver tumors in group II (double dose).

medial lobe, 2 個が right medial lobe, 3 個が right lateral lobe, 1 個が caudate lobe に認められた。また これらの動物では肝以外にはいずれの部位にも腫瘍の 発生はなく，原発性肝腫場と考えられた，組織学的に 腫煬は I・II群ともに主として trabecular patternを 呈し胞体は basophilic で核は大きく hyperchromatic で，核・胞体比が大さ，異常分裂像も散見され，高 分化型肝細胸癌であった，焉た核分裂像は一般にI群 に比べII群の方が多く認められた（Fig. 4, 5)。

なお I 群38匹中 1 匹に乳腺線維腫を，II 群27匹中 1 匹に皮下線維肉腫の発生を認めているが，これら 2 匹 では肝癌の発生を認めていない，一方，対照としたIII 群・IV群では肝過形成結節や肝腫場の発生はなく，ま

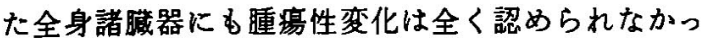
た.

2. 合成女性ホルモン投与中止後の肝細胞癌の変化 (Table 3)

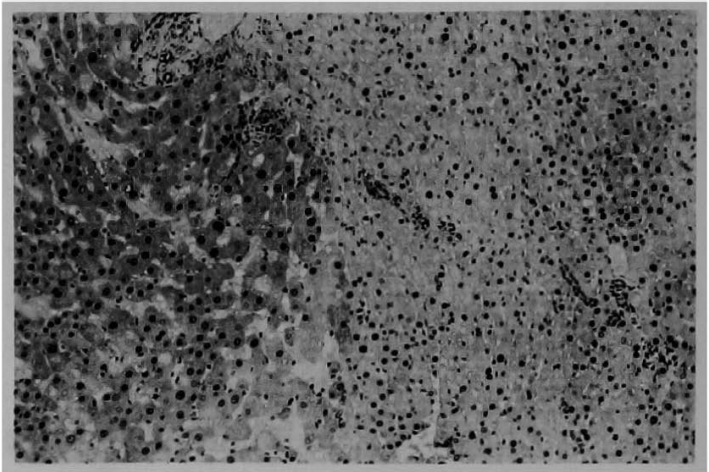

Fig. 4 Microscopic findings of the same tumor as Fig. 3 (A), showing well-differentiated hepatocellular carcinoma. See the border line between the tumor (left) and the surrounding normal liver tissue (right). H.E stain, $\times 200$.

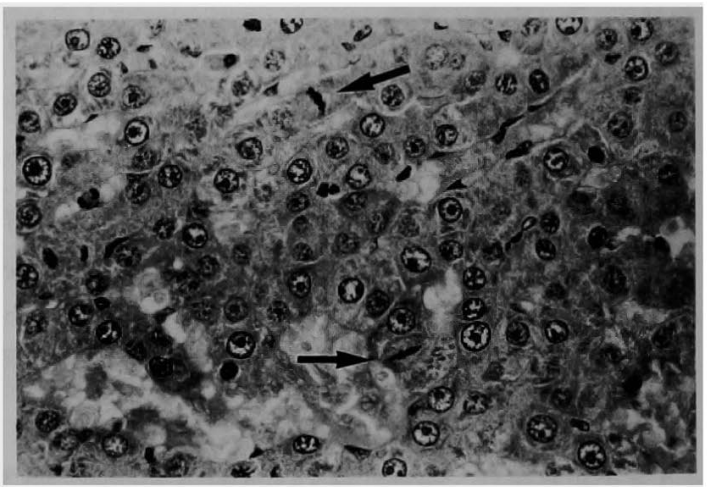

Fig. 5 Microscopic findings of the same tumor as Fig. 3 (B). showing basophilic cytoplasm, prominent nucleoli and mitotic figures (arrow) $\mathrm{H}-\mathrm{E}$ stain. $\times 400$.

I 群に発生した肝細胞癌 6 匹中 4 匹, II 群に発生し た肝細胞癌 6 匹中 2 匹の計 6 匹につき，合成女性ホル モンの投与を中止した後の肝細胞癌の変化を経時的に

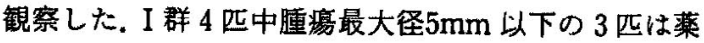
剂投与中止後 2 カ月で肉眼的に腫場を確認できなくな り, 組織学的にも尰湯の存在した部位に線維化をみる のみで腫湯は完全に消失していた，一方，I 群の腫瘍 径 $6 \times 5 \mathrm{~mm}$ の 1 匹と II 群の 2 匹(いずれも腫瘍径 20 $\mathrm{mm}$ 以上）では薬剤投与中止後肉眼的にしだいに肝腫 場は樎少し(Fig. 6), 組織学的にむ肝細胞癌の萎縮や 脂肪浸潤, 空胞変性, 線維化などが認められた(Fig. 7, 8).一方, 非腫掦部の肝細胞には全く変化を認めなかっ た. 
Table 3 Sequential changes of hepatocellular carcinoma following withdrawal of the hormone administration.

\begin{tabular}{|c|c|c|c|c|}
\hline \multirow[b]{2}{*}{ dose } & \multirow[b]{2}{*}{$\mathrm{Na}$} & \multicolumn{3}{|c|}{ Tumor Diameter } \\
\hline & & $\begin{array}{l}\text { at the end of t } \\
\text { administration fo }\end{array}$ & $\begin{array}{l}\text { hormone } \\
12 \text { months }\end{array}$ & $\begin{array}{l}\text { after withdrawal of the hormone } \\
\text { administration } \\
1 \quad 2 \quad 3 \quad 4 \text { months }\end{array}$ \\
\hline $\begin{array}{l}\text { single } \\
\text { dose }\end{array}$ & $\begin{array}{l}1 \\
2 \\
3 \\
4\end{array}$ & $\begin{array}{c}\text { left lateral lobe } \\
" \\
" \\
"\end{array}$ & $\begin{array}{l}4 \times 4 \mathrm{~mm} \\
5 \times 5 \mathrm{~mm} \\
2 \times 3 \mathrm{~mm} \\
6 \times 5 \mathrm{~mm}\end{array}$ & $\begin{array}{l}\text { Regression } \\
\longrightarrow \text { Regression } \\
\longrightarrow \text { Regression } \\
\longrightarrow 4 \times 4 \mathrm{~mm} \longrightarrow 4 \times 3 \mathrm{mmt}\end{array}$ \\
\hline $\begin{array}{l}\text { double } \\
\text { dose }\end{array}$ & $\begin{array}{l}5 \\
6\end{array}$ & $\begin{array}{c}\text { left medial lobe } \\
"\end{array}$ & $\begin{array}{l}20 \times 20 \mathrm{~mm} \\
22 \times 22 \mathrm{~mm}\end{array}$ & $\begin{array}{l}15 \times 13 \mathrm{~mm} \longrightarrow 9 \times 9 \mathrm{~mm} t \\
8 \times 5 \mathrm{~mm}-6 \times 4 \mathrm{~mm} t\end{array}$ \\
\hline
\end{tabular}

t : sacrifice

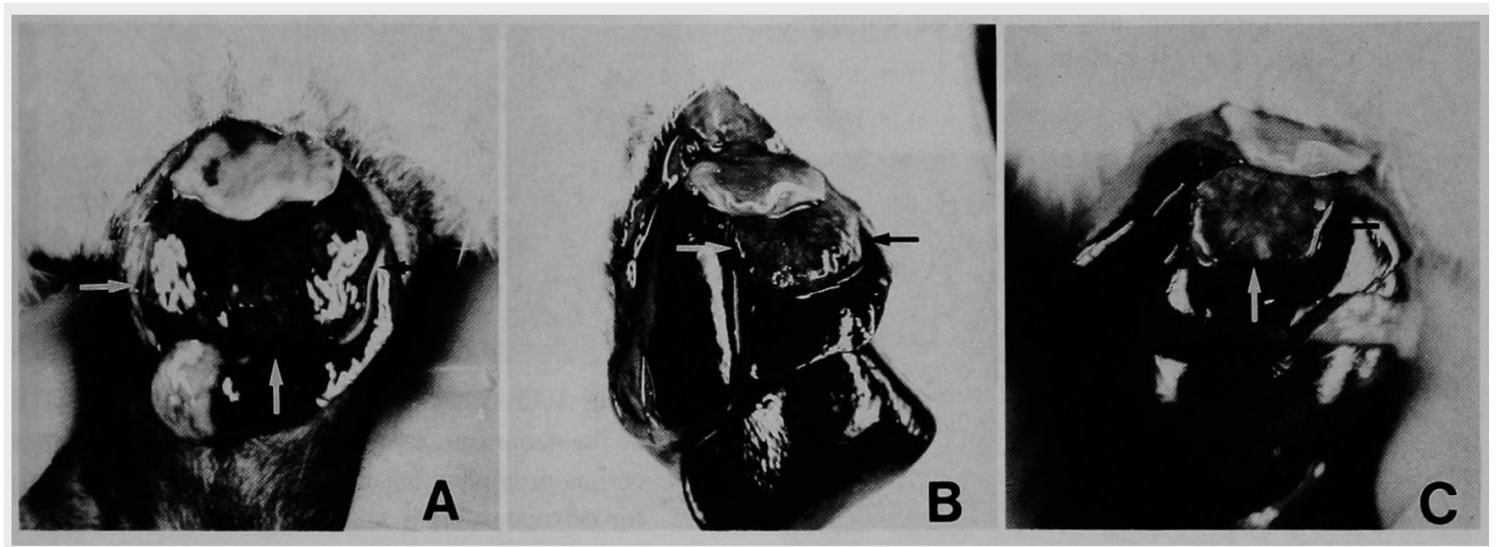

Fig. 6 Sequential changes of macroscopic appearance of hepatocellular carcinoma in group II (double dose) following withdrawal of the hormone admin. istration. (A) : liver tumor developed at the end of the hormone administration during 12 months. (B): the same tumor, 1 month after withdrawal of the hormone administration. (C) : the same tumor, 3 months after withdrawal of the hormone administration.

\section{実験 II：肝組織内 estrogen receptor の検索}

\section{1. 生化学的検索}

合成女性ホルモンの投与を12カ月間完了後, 非発癌 ラット 3 匹 ( I 群) の肝組織, 発癌ラット 2 匹 (II 群) の肝の腫瘍部及び非腫煌部，対照として菜剂を投与し ていない正常ラット3匹の肝組䅧を用いdextran coated charcoal 法にて estrogen receptor たところいずれる estrogen receptor 陽珄であり，各 肝組織の間で解離定数及び最大結合部位数のいずれで る有意差を認めなかった（Table 4).

\section{2. 組織化学的検索}

肝細胞癌を発生したI群 1 匹と II 群 1 匹及び正常 ラット 2 匹の計 4 匹について肝組織内の estrogenを peroxidase-antiperoxidase DeLellis 変法により検索 したところ，正常肝細胞とI 群及びII 群の非癌部肝細 胞はその核とごく少数の細胞質が陽性に染色されたた けであったが, 癌部では estrogen 强陽性細胞が多数認 められた。しかしその染色性は一様ではなく，細胞質 のみに認められるすの，核内のみに認められるもの， その両者に認められるもの，核内・細胞質ともほとん ど染色されないものなど多彩であった（Fig. 9).

$$
\text { 考察 }
$$

一般に経口避妊薬は合成女性ホルモンである estrogen と progestogenの合剂である，合成 progestogen としては norethynodrel, norethindrone acetate, norethindrone, norgestrel, ethinodiol 


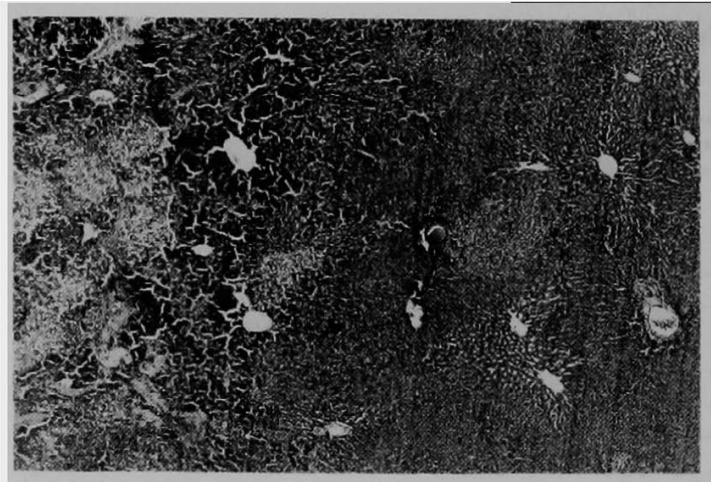

Fig. 7 Microscopic findings of the same hepatocellular carcinoma as Fig. 6 (C). See the border line between the tumor (left) with vacuolar degeneration and surrounding normal liver tissue (right). H-E stain, $\times 40$.

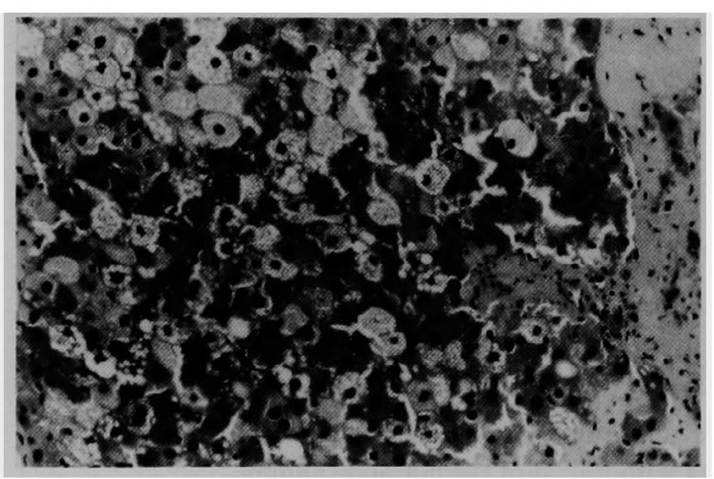

Fig. 8 High magnified picture of the same hepatocellular carcinoma as Fig. 7, showing prominent vacuolar degeneration in the tumor cells. $H$ E stain, $\times 200$.

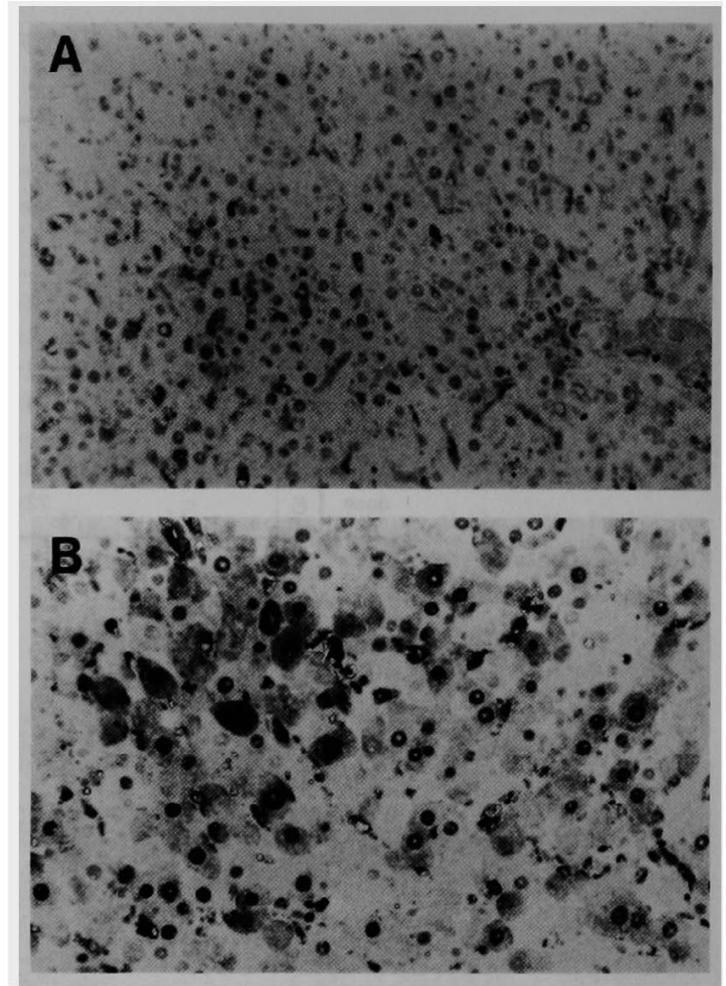

Fig. 9 PAP stain (Immunoperoxidase-estradiol) of the same tumor as Fig. 3 (A), (A) : non-cancerous area showing a weakly positive reaction for estrogen within nucleus alone. $(\times 400)$. (B): cancerous area showing a positive reaction for estrogen within the cytoplasm and, or the nucleus. (Immunoperoxidase-estradiol) $(\times 400)$.

diacetate, medroxyprogesterone acetate, chlomadinone, dimethisterone 98 種類が使用され ているが，これらの間で肝腫湯の発生頻度に有意差は

Table 4 Estrogen Receptor in the liver tissue.

\begin{tabular}{|c|c|c|c|c|c|}
\hline \multirow{2}{*}{$\begin{array}{c}\text { Drug } \\
\text { Administration }\end{array}$} & \multirow{2}{*}{\multicolumn{2}{|c|}{$\begin{array}{l}\text { Examined } \\
\text { Liver }\end{array}$}} & \multicolumn{3}{|c|}{ Estrogen Receptor } \\
\hline & & & $\mathrm{Kd}\left(10^{10} \mathrm{~mol} / \mathrm{L}\right)$ & $\begin{array}{l}\text { Binding (fmol/mg) } \\
\text { Sites }\end{array}$ & Estimation \\
\hline \multirow{2}{*}{$\begin{array}{l}\text { Hormone with } \\
\text { olive oil }\end{array}$} & $\begin{array}{l}\text { no tumor } \\
\text { bearing rat }\end{array}$ & $\begin{array}{l}1 \\
2 \\
3\end{array}$ & $\begin{array}{l}4.96 \\
2.87 \\
4.01 \\
\end{array}$ & $\begin{array}{l}70.1 \\
26.7 \\
12.9\end{array}$ & $\begin{array}{c}\text { positive } \\
\text { " } \\
\text { " }\end{array}$ \\
\hline & $\begin{array}{cc} & 4 \\
\text { tumor } & 4 \\
\text { bearing rat } & 5\end{array}$ & $\begin{array}{l}4 A \\
4 B \\
5 A \\
5 B\end{array}$ & $\begin{array}{l}3.40 \\
5.83 \\
0.89 \\
1.03\end{array}$ & $\begin{array}{l}18.1 \\
21.9 \\
24.5 \\
25.4\end{array}$ & " \\
\hline Olive oil alone & & $\begin{array}{l}6 \\
7 \\
8\end{array}$ & $\begin{array}{l}4.15 \\
4.91 \\
2.11\end{array}$ & $\begin{array}{l}71.4 \\
10.5 \\
51.5\end{array}$ & " \\
\hline
\end{tabular}

A : tumor tissue B : non tumor tissue

* Positive : Kd $1 \times 10^{\prime} \mathrm{mol} / \mathrm{L}$, Binding Sites $>6 \mathrm{fmol} / \mathrm{mg}$ 
みられない.一方, 合成 estrogen は mestranol と ethinylestradiol $の 2$ 種類が使用されており，水本ららの 集計によると肝腫場の認められた291例中 mestranol 服用例は204例 (70.1\%), ethinylestradiol 服用例は57 例 (19.6\%) で両者を服用したものは30例（10.3\%） であり，肝腫場の発生は mestranol 服用例に多いが， これは mestranol が ethinylestradiol に比し約 5 年早 く開発され経口避妊薬として使用されている事実を考 虑すると，必ずしも mestranol が ethinylestradiol 上 り発癌との因果関係が強いと結論することはできな い.

さてGoldfarb"11はこれらホルモン自体か，(1) weak carcinogen として作用する，(2)一部腸内細菌により分 解されることにより carcinogenic compound となる, (3) microsomal drug metabolizing systems することにより他の化合物が carcinogen となるのを 誘導する等の可能性を想定しているが，いずれる証明 されていない。

女性ホルモン単独の肝に対する発癌性に関しては， Reznik-Schüller ${ }^{12)}$ は雄性 hamster の皮下に diethylstilbestrol (DES) 含有 pellet を挿入し肝細胞 腺腫, 胆管細胞癌, 肝細胞癌などの発生を認めており， 本邦では角ら ${ }^{131}$ が WF 系雄性ラットにやはりDES 含 有 pelletを背部皮下に插入し肝細胞癌の発生を認め て㧍り、いずれる DESが weak carcinogenとして作 用する可能性のあることを示唆している. 又 Wanless' ${ }^{14}$ は DES を雄性及び雌性 Fischer-344ラット に, 1 回量 $5 \mathrm{mg}$ あるいは0.5mg を週 2 回, 最高50週間 にわたり経口投与していずれも肝過形成巣の発生を認 めており，DESが complete carcinogen として作用す る可能性を示唆しているが, DES は ethinylestradiol や mestranol とは異なりホルモン作用を示すだけで はなく、肝細胞障害性に働くことが認められており ${ }^{13}$, 肝に対し他の女性ホルモンとは異なった効果を示すむ のと考えられる。

さてDES を除いて合成女性ホルモン単独経口投与 による肝発癌に関する研究には Committee on Safety of Medicines (London) ${ }^{71}$ の報告があり，雄性ラットで は norethinodrel 投与群で24.1\%, norethinodrel+ mestranol 投与群では29.1\%に良性の肝腫㕫の発生を 認めているが, 雌性ラットでは ethinylestradiol + norethindrone acetate 投与群でわずか $1 \%$ に良性肝腫場 の発生を認めているにすぎず，また投与期間が 2 年間 とい5長期間のため対照群にも $2 \%$ に肝腫掦の発生を
認めており，雌性ラットでは合成女性ホルモン投与に よる有意の肝畽湯の発生は示されていない。しかし Yager ${ }^{15)}$ は雌性 Sprague-Dawley 禾ラットに mestranol p norethinodrel を飼料に混してそれぞれ 4 力 月間及び 9 力月間投与して肝過形成結節の発生を認め ており，これら合成女性ホルモンは promoter の作用 たけでなく complete carcinogen として働く可能性を 示唆している.

教室の東ら゙は経口投与により薬剤が門脈を通って 肝に到達することの重要性に着目し，一般に肝癌自然 発生の少ない雌性 Wistar 系ラットを用い経口避妊薬 の配合にあわせて ethinylestradiol と norethindrone acetate とを硬性胃ソンンデにより，1年間連日強制的 に経口投与して全例の肝に過形成結節の発生を認め, さらにその 1 例に高分化型肝細胞癌の発生を認め, 合 成女性ホルモンが肝発癌の initiatorとして作用する 可能性を示唆した。 また教室の富田9は合成女性ホル モンの投与量を倍にすることにより発生する肝過形成 結節の数。面積はそれぞれ有意に増加し, 肝癌発生率 も有意に増加することを明らかにし，教室の今井 ${ }^{101}$ これらの変化を経時的に観察して合成女性ホルモンの 投与開始後 4 力月目から全例の肝に過形成結節の発生 を認め，以後投与期間の延長とともにその数や面積が 増加し, ついで 8 カ月目上り高分化型肝細胞癌の発生 を認め，さらに合成女性ホルモンの投与を中止すると これらの過形成結節はしだいに消失することを報告し てそのホルモン依存性を示した。

一方臨床例では Bühler ${ }^{16)} 5$ 年以上の経口避妊薬 服用後 liver cell adenoma が発生した 3 女性の経過を 観察し, 服薬中止後 7 カ月から 4 年で, 理学的あるい は肝シンチグラムや腹部超音波検查などの画像診断上 で虐瘤の消失を認めたと報告しており，他方 Mariani ${ }^{17)}$ が経口避妊菜服用中止後も肝細胞腺腫が増 大した 1 例を報告するに及んでそのホルモン依存性が 問題となってきた。一方 Eisenfeld ら ${ }^{18}$ は必ずしもホ ルモン標的臓器とはいえない肝にも estrogen receptorが存することを報告しており，さらに MacDonald ${ }^{19}$ ( は経口避妊薬服用者に発生したfocal nodular hyperplasia (FNH) の estrogen receptor を 測定し, $\mathrm{Kd}=4.0 \times 10^{-9} \mathrm{M}$, max binding sites 47.9 $\mathrm{fmol} / \mathrm{mg}$ で estrogen receptor は陽性であったと述べ ている.

本研究では合成女性ホルモンの経口投与により肝細 胞癌が発生し，ホルモン投与を中止すると発生した肝 
細胞癌は次第に樎少し退樎することを明らかにしてそ のホルモン依存性を示すことがでさた。ささらにラット では正常肝でも estrogen receptor が証明され，合成 女性ホルモンを投与するとこれが肝に集積し，かつ発 生した肝細胞癌では estrogen 強陽性細胞が多数認め られたことなどから．合成女性ホルモンの肝発癌性に おける estrogen receptorの関与が示唆された。

\section{結 語}

Wistar/JCL 雌ラットを用いた経口避妊薬の配合に あわせて ethinylestradiol と norethindrone acetate の合成女性ホルモンを 1 年間連日強制的に経口投与し て次の結果を得た。

1）薬剂投与終了の時点で全例の肝に過形成結節の 発生を認め,さらに 1 日投与量 ethinyl estradiol 0.075 $\mathrm{mg}$, norethindrone acetate $6 \mathrm{mg} の \mathrm{I}$ 群では15.8\%, 倍量投与のII群では $22.2 \%$ に肝細胞癌の発生を認め た.

2）発癌ラット6匹を用い合成女性ホルモンの投与 を中止して，以後 1 カ月毎に開腹し肝腫瘍の变化を観 察したところ，腫瘍はしたいに縮少し組織学的にも腫 湯細胞の萎縮や変性が認められた。

3）合成女性ホルモンの投与により発生した肝細胞 癌は estrogen receptor 陽性であり, 組織化学的にも 瘇瘍部に多数の estrogen 強陽性細胞を認めた。

以上の結果より ethinylestradiol 及び norethindrone acetateよりなる䅅口避妊薬は単独で訮癌を発 生し,しかもその肝腫湯は強いホルモン依存性を示し, かつこれらの発現の上で estrogen receptorの関与が 示唆された。

稿を終るにのぞみ御指導，御校閲を賜わった办本龍二教 授に深甚なる謝意を捧げると共に，終始御指導御協力を戴 いた福井医科大学病理学教室中久木和也教授, 三重大学病 理学教室矢谷隆一講師及び協同研究者の三重大学第 1 外科 学教室東 俊策, 富田 隆, 今井俊積各博士に深謝致しま す。また本研究で得られた肝細胞癌の診断につき御教示い ただいた癌研究所実験病理!部高山昭三部長，名古屋市立大 学病理学教室伊東信行教授に心から感謝致します。

本論文の要旨は第20回日本肝荿学会総会並びに第43回日 本癌学会総会において発表した。

\section{文献}

1) Caroli JJ, Paraf A, Charbonnier A, et al: Implantation d'oestrogenes apparemment suivies d'un cancer primitif du foie. Rev Int Hepatol 3 : $497-509,1953$
2) Bernstein MS, Hunter RL, Yachnin S: Hepatoma and peliosis hepatis developing in a patient with Fanconi's anemia. N Engl J Med 287 : 1135-1136, 1971

3) Horvath E, Kovacs K, Ross RC: Ultras tructural finding in a well-differentiated hepatoma. Digestion $7: 74-82,1972$

4) Baum JK, Holtz F, Bookstein JJ, et al : Possible association between benign hepatoma and oral contraceptives. Lancet 2 : 926-929, 1973

5）水本龍二, 東 拨策, 冨田 隆, 他：経口避妊薬と 肝癌。肝胆膵 5(6): 1007-1012, 1982

6) Schardein JL, Kaump DH, Woosley ET, et al : Long-term toxicologic and tumorigenesis studies on an oral contraceptive agent in albino rats. Toxicol Appl Pharmacol 16:10-23, 1970

7) Carcinogenicity Tests of Oral Contraceptives, Report of the Committee on Safety of Medicine, Her Majesty's Stationary Office. London, 1972

8) Higashi S, Tomita T, Mizumoto R, et al: Development of hepatoma in rats following oral administration of synthetic estrogen and progestogen. Gann $71: 576-577,1980$

9）富田 隆：経口避妊薬. 合成女性ホルモンによる 実験肝癌発生の研究. 肝缄 $23: 57-64,1982$

10）今井俊積：経口辟妊薬(合成女性ホルモン)による 肝癌発生の実験的研究. 特に肝過形成結節並びに 肝細胞癌発生の経時的検索之薬剂投与中止の効 果. 肝臓 $24: 182-192,1983$

11) Goldfarb S: Sex hormones and hepatic neoplasia. Cancer Research 36 : 2584-2588, 1976

12) Reznik-Schüller $H$ : Carcinogenic effects of diethylstilbestrol in male syrian golden hamsters and European hamsters. J Natl Cancer Inst $62: 1083-1088,1979$

13) Sumi $C$, Yokoro $K$, Matsushima $R$ : Induction of hepatic tumors by diethylstilbestrol alone or in synergism with n-nitrosobutylurea in castrated male WF rats. J Natl Cancer Inst $70: 937$ $-942,1983$

14) Wanless IR, Medline A : Role of estrogens as promoters of hepatic neoplasia. Lab Invest 46 : 313-320, 1982

15) Yager JD Jr: Oral contraceptive steroids as promoters or complete carcinogens for liver in 
female Sprague-Dawley rats. Environ Health Perspect $50: 109-112,1983$

16) Buihler H, Pirovino M, Akovbiantz A, et al: Regression of liver cell adenoma: A follow-up study of three concecutive patients after discontinuation of oral contraceptive use. Gastroenterology $82: 775-782,1982$

17) Mariani AF, Livingstone AS, Pereiras RV Jr, et al : Progressive enlargement of a liver cell adenoma. Gastroenterology $77:$ 1319-1325, 1979

18) Eisenfeld AJ : Estrogen receptor in the mam. malian liver. Science $191: 862-865,1976$

19) MacDonald JS, Lippman ME, Wooley PV, et al: Hepatic estrogen and progesterone rece. ptors in an estrogen-associated hepatic neoplasm. Cancer Chemother Pharmacol 1: 135 $-138,1978$

\section{Experimental studies on hepatocarcinogenesis by oral contraceptives, synthetic estrogen and progestogen, with special reference to the hormone dependency of the developed hepatocellular carcinoma}

\section{Shin-ichi UEHARA*}

The purpose of this study was to investigate on the hepatocarcinogenicity of the long term administration of oral contraceptives and on the hormone dependency of the developed tumor. Female rats of the Wister strain aged 4 weeks were used. In group I, rats were given a daily dose of $0.075 \mathrm{mg}$ of ethinylestradiol and $6 \mathrm{mg}$ of norehindrone acetate dissolved in $0.5 \mathrm{~m} l$ of olive oil, through a gastric tube without anesthesia for 1 year. In group II, rats were given double the daily dose of group I for 1 year. In group III and IV, rats were given $0.5 \mathrm{~m} l$ and $1.0 \mathrm{~m} l$ of olive oil alone for 1 year as a control for group I and II, respectively.

Although none developed any tumors in the liver and the other tissue in group III and IV, six of 38 rats $(15.8 \%)$ in group I and six of 27 rats $(22.2 \%)$ in group II developed liver tumors, which were histologically well-differentiated hepatocellular carcinoma. These tumors had estrogen receptor, and regressed gradually following withdrawal of hormone administration. Histochemical assays showed that the most tumor cells demonstrated positive for estrogen-staining in nucleus or cytoplasm, or both.

This study revealed that oral contraceptives induced hepatocellular carcinoma, which had estrogen receptor and the hormone dependency, and suggests that oral contraceptives might be one of carcinogens and act as the initiator.

* The First Department of Surgery, Mie University School of Medicine (Tsu)

(Director: Prof R. MIZUMOTO) 